\title{
The potential of population and housing censuses for international migrant analysis ${ }^{1}$
}

\author{
Sabrina Juran* and Rachel C. Snow \\ United Nations Population Fund, Technical Division, Population and Development Branch, 605 Third Avenue, New \\ York 10158, NY, USA
}

\begin{abstract}
International migration is of major relevance for the development of countries of origin, transit and destination. While the proportion of the world population who live outside their countries of birth has stayed relatively stable over time, the absolute number of international migrants reached 244 million in 2015. International migration has been recognized as a driver of development in both countries of origin and destination, and in turn, patterns of global development both strongly impact, and are impacted by, migration.

Data sources to inform the issue of international migration include decennial population and housing censuses, population registers, civil registration and other administrative data, residence permits and various household surveys. While providing a valuable source of data on international migration, censuses are sometimes conducted infrequently or the data from census are not fully released, or remain under-analyzed. This paper reports on the availability of migration data from all national population censuses by countries that participated in the 2010 census round, and highlights the potential of these data for the generation of migration profiles and analysis on the character of international migration especially within the context of monitoring and reporting the sustainable development goals.
\end{abstract}

Keywords: Census, international migration, migrant, sustainable development goals, population, data for development

\section{Background}

International migration is of major relevance for the development of countries of origin, transit and destination. While the proportion of the world population who live outside their countries of birth has stayed relatively stable over time (3.4\% in 2015), the absolute number of international migrants reached 244 million in 2015 [1]; it had increased from 153 million in 1990 (2.9\%), to 173 million (2.8\%), to 222 million in 2010 $(3.2 \%)$.

Based on estimated from the United Nations Population Division, the international migrant stock could increase to 578 million, if the growth rate from 2000

\footnotetext{
${ }^{1}$ The views expressed in this paper are entirely those of the authors and do not reflect those of their employer.

* Corresponding author: Sabrina Juran, United Nations Population Fund, Technical Division, Population and Development Branch, 605 Third Avenue, New York, NY, 10158, USA. E-mail: sabrinajuran@ gmail.com.
}

to 2010 were applied. Applying the growth rate from 2010 to 2015 would result in a migrant stock of 469 million.

International migration has been recognized as a driver of development in both countries of origin and destination, and in turn, patterns of global development both strongly impact, and are impacted by, international migration.

International migratory movements are impacting population change all over the world. While migration is slowing the pace of population decline, although not bringing it to a halt in Europe, migration is reducing population growth, even though with little impact in Africa.

With the adoption of the 2030 Agenda for Sustainable Development in September 2015 and the focus within the Agenda of integrating international migration within global development policy, the international community agreed to create a coherent and comprehensive policy framework, "to ensure safe, orderly 
and regular migration involving full respect for human rights and the humane treatment of migrants regardless of migration status, of refugees and of displaced persons" [2].

The General Assembly agreed on 17 Sustainable Development Goals (SDGs), 169 targets and 232 indicators aimed at reducing poverty and ensuring sustainable development. The declaration includes various indicators that relate directly or indirectly to migration, including 10.7.1 "Recruitment cost borne by employee as a proportion of yearly income earned in country of destination"; 10.7.2 "Number of countries that have implemented well-managed migration policies"; 8.8.1 "Frequency rates of fatal and non-fatal occupational injuries, by sex and migrant status"; and 8.8.2 "Increase in national compliance of labour rights (freedom of association and collective bargaining) based on International Labour Organization (ILO) textual sources and national legislation, by sex and migrant status".

In order to achieve sustainable development beneficial to all people, without distinction of any kind such as migratory status, disaggregated data are of utmost importance. The SDG indicator that best advances the likelihood that the status, rights and well-being of migrants will be tracked over the coming 15 years is 17.18.1, "Proportion of sustainable development indicators produced at the national level with full disaggregation when relevant to the target, in accordance with the Fundamental Principles of Official Statistics", because the corresponding target (17.18) calls to define and include migratory status within the list of factors for expected disaggregation of all SDG indicators.

17.18 "By 2020, enhance capacity-building support to developing countries, including for least developed countries and small island developing States, to increase significantly the availability of high-quality, timely and reliable data disaggregated by income, gender, age, race, ethnicity, migratory status, disability, geographic location and other characteristics relevant in national contexts."

The New York Declaration for Refugees and Migrants (A/RES/71/1) recognizes the importance of improved data collection, particularly by national authorities, and the need to enhance international cooperation to this end, including through capacity-building, financial support and technical assistance. Such data should be disaggregated by sex and age and include information on regular and irregular flows, the economic impacts of migration and refugee movements, human trafficking, the needs of refugees, migrants and host communities and other issues. States agree to do so consistent with our national legislation on data protection, if applicable, and our international obligations related to privacy, as applicable.

The potential impact of including this simple clause cannot be over-estimated for advancing research on the status and trends of migrant health, education, employment, experience of discrimination or violence, access to mobile or other assets, and a wide range of other benefits and/or deprivations $[3,4]$. Despite increasing research on the link between migration and development; the scope and scale of the phenomenon as well as its relation with development is not yet fully understood, and the emerging SDG indicator data could provide a huge advance in our current knowledge, which is hindered by limited availability of timely, reliable and quality statistics. While numerous data sources exist that could be drawn on for migration research, comprehensive and accurate data on the migrants are not readily available for all countries in the world. Further, in many instances data sources, such as the population and housing census that could yield valuable information on the phenomenon of international migration, are oftentimes under utilized.

The paucity of quality migration data and analysis has long been recognized and requires major investment. Figure 3 shows the availability of empirical data on the number of international migrants for the time period between 1995 and 2015. Data sources to inform the issue of international migration include decennial population and housing censuses, population registers, civil registration and other administrative data, residence permits and various household surveys, including labour force surveys. But many household surveys have long lead times, which diminished their value, especially in circumstances of rapid migration.

"In countries that have a population register and in those that use residence permit data, stocks and flows of immigrants are most often calculated using the same source. [...] Some countries instead use census or labour force survey data to estimate the stock of the immigrant population. [... many labour force surveys now include questions about nationality and place of birth, thus providing a source of annual stock data. However, some care has to be taken with detailed breakdowns of the immigrant population from survey data, as sample sizes can be small. [...] To this must be added the difficulty of purging data files regularly to eliminate permits that have expired" [5].

Population censuses are perhaps the most comprehensive data source of internationally comparable data 


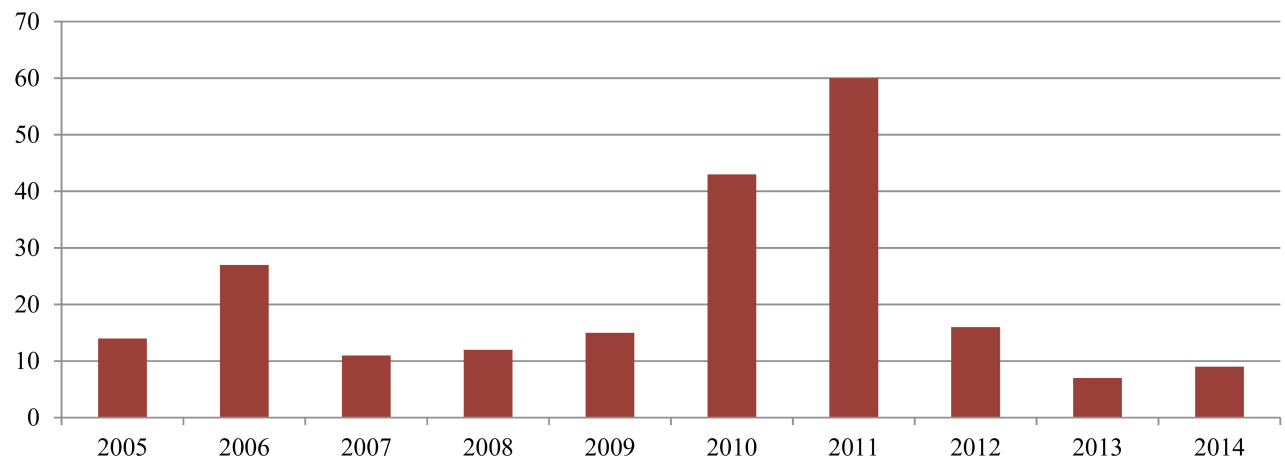

Fig. 1. Number of countries conducting a census in the 2010 round. Source: Own calculations based on United Nations Department of Economic and Social Affairs: Statistics Division (2016).

on international migration in the world. The unique benefit of a population and housing census, despite infrequent conduct, is that it "represents the entire statistical universe, down to the smallest geographical unit, of a country or region" [6]. Another strength stems their potential for permitting the characterization of international migrants in terms of certain demographic and socio-economic characteristics. "Because population censuses can accommodate only a small number of questions eliciting straightforward answers, they cannot introduce much variability in the range of questions used. As such, there is greater uniformity in the type of data they produce than for any other data source" [7].

While providing a potentially valuable source of data on international migration, censuses have a number of limitations. Most countries in the world carry out a census only once every ten years. As such, they cannot provide information on rapid changes in the population or the issue of international migration. Further, due to its limited number of questions, they cannot provide detailed information needed for meaningful analysis of either determinants or consequences of international migration. "Third, most censuses fail to achieve complete and accurate count, and it is quite possible that the degree of accuracy with which they cover international migrants is even lower, especially if international migrants have a vested interest in avoiding being counted or in misreporting their migrant status." Moreover, another drawback might be "that countries use different approaches to define the enumerated population. Censuses may aim at enumerating the de facto population, and thus include all persons physically present in the country at the census reference date, or they may cover only the de jure population, covering only usual residents of the country in question, some of whom may not be physically present in

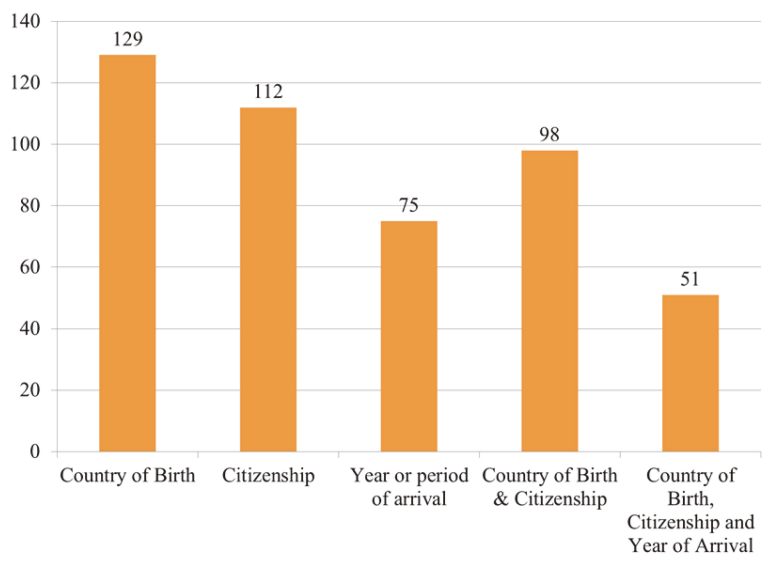

Fig. 2. Summary of the availability of core migration questions in national population and housing censuses. Source: Own calculation based on United Nations Department of Economic and Social Affairs: Statistics Division (2016).

the country at reference date" [8]. Because of those different approaches, it is therefore possible that some groups end up being included or excluded from the census of their country of origin and destination on arbitrary grounds. Inevitably, census data underestimate the number of migrants or undocumented migrants, in particular when migrants do not register for census purposes [9].

Population censuses nonetheless provide the most comprehensive source of internationally comparable information because they include questions that can generate information at low levels of resolution relevant to the phenomenon of international migration, including details on country of birth, country of citizenship, country of residence one year or five years prior to the census, and year of arrival in the country [10].

High-density census data, which are part of the existing statistical infrastructure of most countries, allow for disaggregation of the national population by sex, 


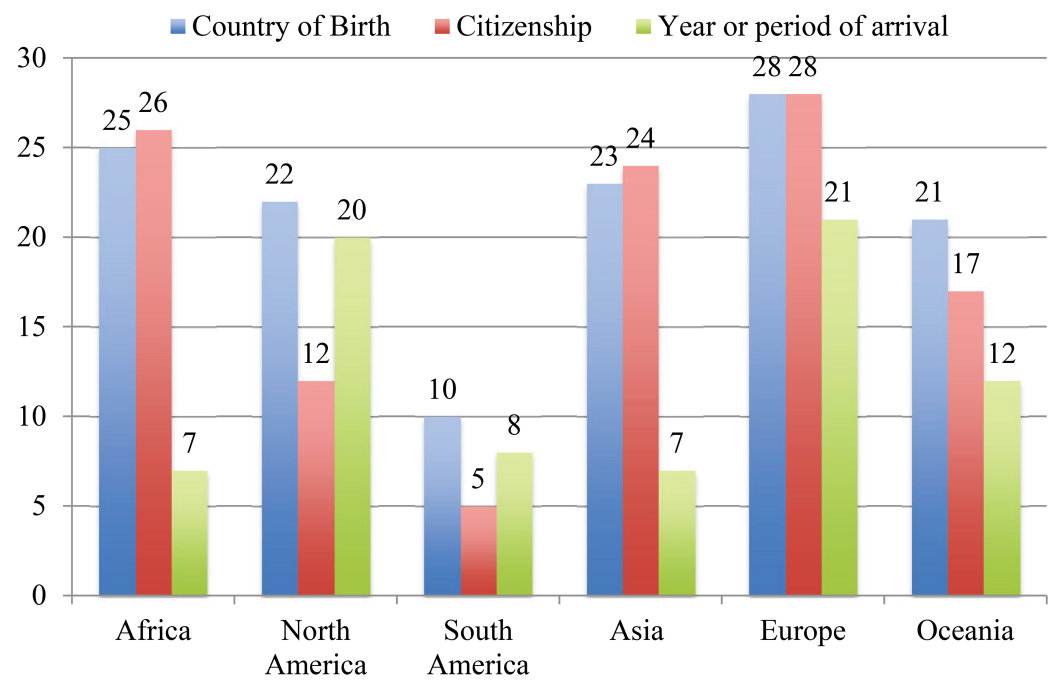

Fig. 3. Number of censuses including the individual core questions related to international migration in questionnaires of the 2010 census round, by region. Source: Own calculation based on United Nations Department of Economic and Social Affairs: Statistics Division (2016).

age, disability, and migrant status, among other factors. As such, national census data will be the most important source of data for fulfilling SDG target 17.18, and disaggregating the range of all other SDGs by migration status [11].

Several internationally agreed definitions exist using a number of criteria to identify international migrants. The UN definition on an international migrant refers to "any person who changes his or her country of usual residence for at least 12 months. Part of this definition is two components: a move and a minimum duration of stay to distinguish long-term from shortterm migrants. The United Nations Population Division bases its migrant stock estimates on the definition of the foreign-born persons in a country for more than one year. Again the time dimension becomes important to ascertain which foreign-born person qualifies for the migrant stock. Anyone under one year of residence is counted to the recent migrant flow. Lastly, the criterion of citizenship is part of the definition of the foreign population, which refers to all persons who have the country of enumeration as the country of usual residence and who are the citizens of another country. However, not all countries can identify migrants based on these definitions.

There are merely one or two countries that can identify a migrant based on the UN definition. Similarly to the 2000 round, where only one country was able to do so [12].

The United Nations Principles and Recommendations for Population and Housing Censuses provide detailed guidelines to national authorities for the col- lection of census data relevant to international migration, including recommended questions for the census instruments. Many countries that conducted a census during the 2010 census round (that spanned from 2005 to 2014) included the recommended questions, shedding light on the year/time of arrival, and from which country, and a wide range of socially important data about how migrants differ (or not) in their social and economic experience by length of stay, country of origin, or from non-migrants.

However, many countries in the world have limited capacities to "carry out policy-relevant analyses on way and means of reaping the benefits of migration for individuals, communities, and societies" [13]. Given that overall existing data on international migration are limited, investment in better migration data in population and housing censuses, and the promotion of greater use of such data is indispensable to understanding the scope of migratory movements, advancing the understanding of the relationship between migration and development, and ultimately informing policy decisions for the well-being of people [14]. Simply assuring that all censuses included comparable migration questions would enable evidence-based advocacy for needed services, avoid confounding factors in programme design, and advance understanding of the relationship between migration and development.

In addition, in an effort to provide access to national statistics and disseminate widely information on population size and composition, the United Nations Statistics Division undertook efforts during the 2010 census round to collect official demographic statistics, includ- 


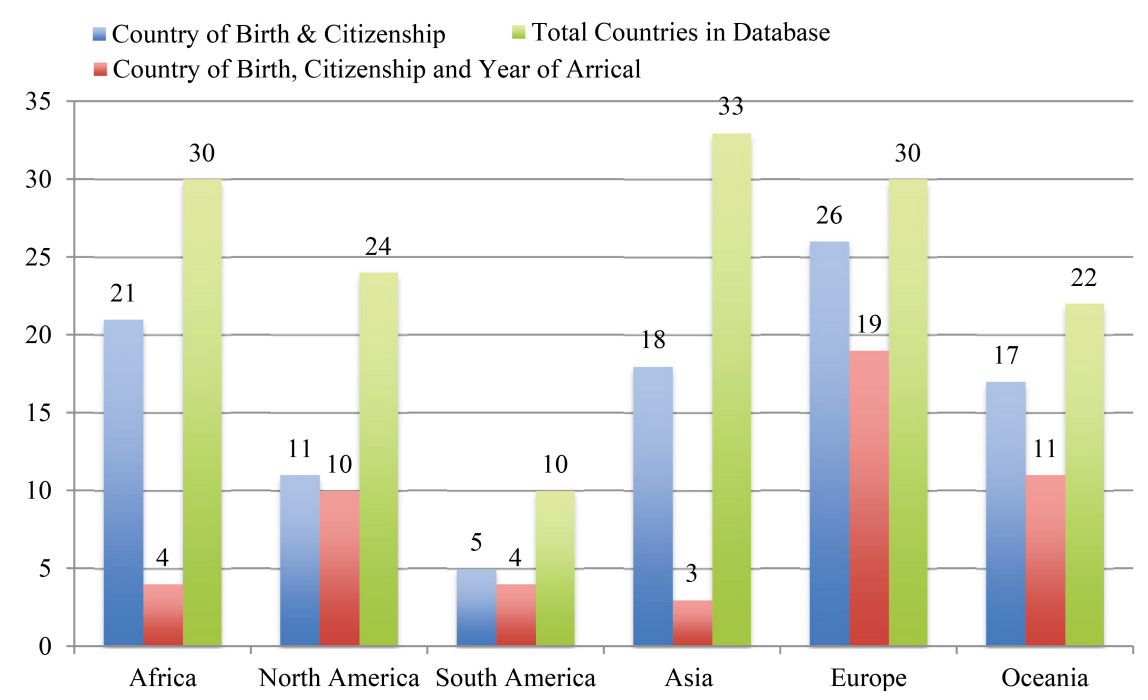

Fig. 4. Number of censuses including two and three core questions in questionnaires of the 2010 census round, by region. Source: Own calculation based on United Nations Department of Economic and Social Affairs: Statistics Division (2016).

ing on migration, from more than 230 countries or areas in the world, published in the Demographic Yearbook. UNSD compiles and disseminates national data on migrant stock and its characteristics electronically through the UN data portal [15] as well as the webbased Demographic Yearbook datasets [16].

Working from the same source material, this paper reports on the availability of international migration data from all national population and housing censuses by countries that participated in the 2010 census round, and highlights the potential of these data for the generation of baseline migration profiles and in-depth analysis on the multifaceted character of international migration.

\section{International migrant data from population and housing censuses}

Ideally every ten years, countries conduct a population and housing census, which is a complex exercise that requires detailed planning of enumeration methods, applied technology, privacy and confidentiality regulations, data collection, data processing and imputation, data analysis and dissemination, archiving, and quality control evaluations of coverage and quality [17]. In many countries, a population and housing census is the principal source of data on the number, distribution and characteristics of a population, including international migrants. Compared to household or population-based surveys or population registers, the unique advantage provided by a population and housing census is the near-universal representation of the population of a country, down to the smallest geographical unit. Depending on the detail of the census questionnaire, this national data collection exercise provides information on the underlying phenomena of social and economic characteristics of the population, and may represent the primary data source for identifying certain social, demographic and economic exclusions and constraints for small geographical areas or sub-populations. While censuses remain the primary source for internationally comparable information on the number and characteristics of international migrants, delays in the processing and dissemination of census results remain challenging.

In the 2010 census round, 214 countries or areas conducted at least one census, including countries that conducted a traditional census in person, by post or online, or based their detailed population "census" statistics on population registers, administrative records, sample surveys, other sources or a combination of these sources. Twenty-one countries or areas did not conduct a population and housing census during the 2010 round [18]

The United Nations Principles and Recommendations for Population and Housing Censuses, Revision 2 [19] by the United Nations Statistics Division (UNSD) advocates for the inclusion of at least three core questions on 1) country of birth, 2) citizenship and 3 ) year or period of arrival to inform the topic of international migration.

The question on country of birth in a national population and housing census allows distinguishing the 


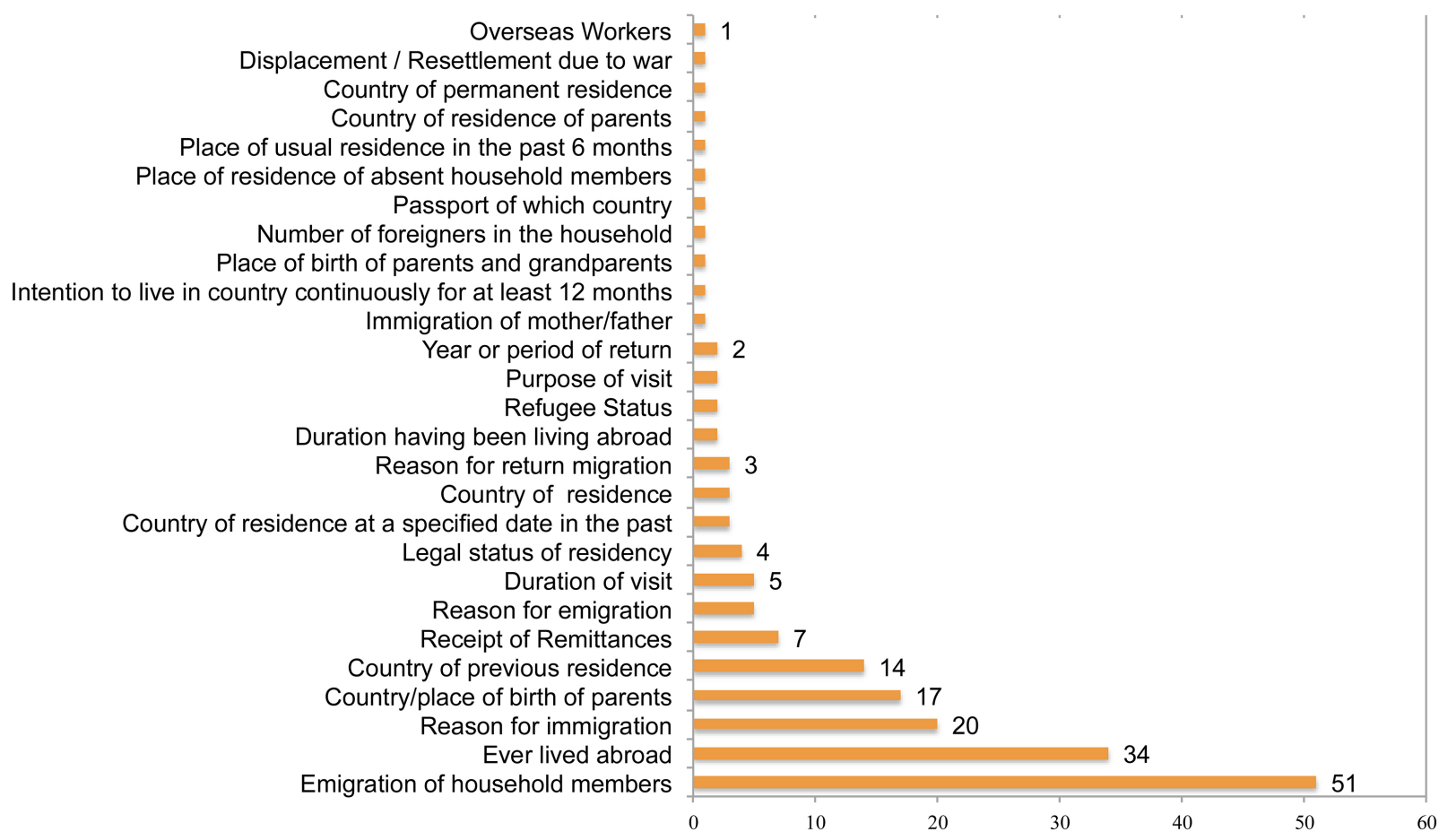

Fig. 5. Frequency of additional questions related to international migration in questionnaires of the 2010 census round. Source: United Nations Department of Economic and Social Affairs: Statistics Division (2016).

native-born from the foreign-born population in the country of enumeration; which means that the foreignborn population has migrated to the country of enumeration at some point in time [20].

Asking the question on citizenship allows analysts to determine migrants' rights and responsibilities in the country of destination. Legal nationality is an identifying factor for international migrants and is further important at the national level to determine which people are subject to border control when crossing international borders.

Information about the country of residence at one year, five years, or ten years prior to the census provides a reference date to international migration during a specific point in in the past.

Questions on time or period of arrival for foreignborn persons in the country of destination, referring to the calendar year and month of arrival of a foreignborn person to the country of enumeration, allow for calculating the duration of stay and classifying migrant populations by time of arrival [21]. Detail on the month and year of arrival allow for the classification of foreign-born by period of arrival in terms of prespecified periods, such as 2005-2009, 2010-02014 and so forth. To check the internal consistency of those data, calculating the duration of stay is notably valu- able if the last place of residence has also been investigated. The duration of residence is expressed in complete years, during which a person has lived in "(a) the locality that is his or her usual residence at the time of the census and (b) the major or smaller civil division in which that locality is situated" [22]. At the same time, the census questionnaire provides for the possibility to collect information on date of first arrival in the country of enumeration or date of the most recent arrival in the country of enumeration. While each has bring along benefits and disadvantages, the decision should ultimately be guided by national policies and user needs.

The census database [23] maintained by the Demographic Statistics Section of the United Nations Statistics Division (UNSD) contains census questionnaires from 149 countries (as of October 2016) that conducted a census in the 2010 census round. This allows the review of 70 percent of all census questionnaires in the world. The inclusion of national census questionnaires from the 2010 census round in the database ranges from 59 percent in Europe to 88 percent for countries in Oceania. Table 1 displays the disaggregation of the number of countries per region that conducted a census and that are included in the database. 
Table 1

Universe of countries in the 2010 census round and the census database of the United Nations Statistics Division

\begin{tabular}{|c|c|c|c|c|c|c|c|}
\hline & Africa & North America & South America & Asia & Europe & Oceania & Total \\
\hline Countries and Territories in the World & 58 & 36 & 14 & 50 & 54 & 25 & 237 \\
\hline Countries with 2010 Census & 49 & 33 & 14 & 43 & 51 & 25 & 214 \\
\hline Countries without 2010 Census & 9 & 5 & 0 & 7 & 2 & 0 & 23 \\
\hline Census Questionnaires in UNSD Database & 30 & 24 & 10 & 33 & 30 & 22 & 149 \\
\hline Questionnaire Availability in UNSD Database & $61.2 \%$ & $72.7 \%$ & $71.4 \%$ & $76.7 \%$ & $58.8 \%$ & $88.0 \%$ & $69.6 \%$ \\
\hline
\end{tabular}

Source: Own calculations based on United Nations Department of Economic and Social Affairs: Statistics Division (2016).

Based on a report filtering questions in national census questionnaires linked to international migration, a summary of questionnaires was created of the three recommended core topics described above. In addition, a second report was run for all other topics related to international migration. This article's findings are based solely on the review of census questionnaires contained in the UNSD census database. Detailed information contained in national census documents or analytical reports were not for the purpose of this review.

\section{Availability of migration data in censuses}

During the 2010 census round, more than 87 percent of the 149 countries for which data are available in the UNSD database integrated a question in their census about country of birth, 75 percent asked for citizenship and 50.3 percent asked for the year or period of arrival (Fig. 2). This suggests that data on international migration could be available for a significant number of countries worldwide, if countries were committed to produce and to disseminate the information in a timely manner.

As displayed in Fig. 5, 129 countries established the total number of foreign-born and native-born people among their population based on the question on "country of birth," representing 87 percent of all countries for which information is available. The question on "citizenship" or "nationality" was included in 112 national census questionnaires, representing 75 percent of the census universe of this paper. Half of all countries asked for the year or period of arrival. When looking at the combination of core questions included in the questionnaire, 66 percent of all countries asked both questions on "country of birth" and "citizenship" and only 34 percent asked all three questions in their latest census [24].

In South America, all ten countries for which information are available collected this information. Also, the majority of countries in Oceania (21 our of 22), Europe (28 out of 30 ), Africa (25 out of 30 ), and North
America (22 out of 24) included the question on country of birth in their 2010 census. In Asia only 23 out of 33 countries asked that specific question. For example, among the countries that did not collect data on country of birth are Ethiopia, Seychelles, DPR of Korea, Japan, Philippines, Vietnam and Switzerland. However, Switzerland includes only census questions in its questionnaire that are not available through its population registers [25]. Other countries intended to collect international migration data between the 2010 and 2000 census round, by adding the question of "residence at last census date" to the 2010 census questionnaire [26].

The question on "citizenship" or "nationality" was included in 112 national census questionnaires [27]. While all but two European countries (28 out of 30; 93\%) and a large majority of countries in Africa (25 out of $30 ; 87 \%$ ) included a question on that topic in their census questionnaire, only fifty percent of all North and South American countries collected these data. In Asia 24 out of 33 countries $(73 \%)$, and in Oceania 17 out of 22 countries (77\%) included this specific question.

The question on year or period of arrival was the least likely to have been asked, among the three recommended questions. Overall, 75 countries $(50 \%)$ asked for the year or period of arrival of the foreign-born member of the population to establish the length of stay of their migrant population. The highest inclusion of the question was found in North (83\%) and South American $(80 \%)$ census questionnaires. On the other hand, only 23 percent of all African census questionnaires and only 21 percent of Asian questionnaires included the question on year or period of arrival. Of the 75 countries that asked the question, the majority of countries formulated the question to investigate the specific date or year of arrival.

Using country of birth as the criterion to identify international migrants ensures that persons considered have actually moved from one country to another; whereas the use of citizenship as the identifying criterion does not. Consequently the best strategy is for censuses to collect data on both, current "citizenship" and 
Table 2

Countries that Included Specific Questions Related to International Migration in the 2010 Census Round

\begin{tabular}{|c|c|}
\hline Topic of question & Countries \\
\hline $\begin{array}{l}\text { Emigration of } \\
\text { household } \\
\text { members }\end{array}$ & $\begin{array}{l}\text { Albania, Algeria, Bahamas, Bangladesh, Barbados, Belize, Bermuda, Bolivia, Botswana, Brazil, Burk- } \\
\text { ina Faso, Burundi, Cameroon, Cayman Island, Colombia, Costa Rica, Croatia, Czech Republic, Djibouti, } \\
\text { Ecuador, Egypt, El Salvador, Estonia, Faeroe Islands, Ghana, Guinea-Bissau, Hungary, Jamaica, Kenya, } \\
\text { Lesotho, Lithuania, Macao SAR of China, Malawi, Mali, Mexico, Micronesia (Federated States of), Mon- } \\
\text { golia, Montenegro, Namibia, Nepal, Nicaragua, Panama, Peru, Philippines, Romania, Saint Helena, Saint } \\
\text { Lucia, Serbia, Singapore, Swaziland, Trinidad and Tobago }\end{array}$ \\
\hline Ever lived abroad & $\begin{array}{l}\text { Albania, Bahamas, Bangladesh, Barbados, Belarus, Belize, Bermuda, Bosnia and Herzegovina, Bulgaria, } \\
\text { Burkina Faso, Burundi, Croatia, Curacao, Cyprus, Estonia, Faeroe Islands, Greece, Hungary, Iran, Ireland, } \\
\text { Israel, Italy, Jamaica, Liechtenstein, Lithuania, Malta, Montenegro, Romania, Serbia, Saint Lucia, Suri- } \\
\text { name, Switzerland, Tokelau, Trinidad and Tobago }\end{array}$ \\
\hline Reason for immigration & $\begin{array}{l}\text { American Samoa, Belarus, Belize, Bhutan, Burkina Faso, Croatia, Egypt, Guam, India, Niue, Northern Mar- } \\
\text { iana Islands, Mauritius, Palau, Russian Federation, Saint Lucia, Thailand, Timor Leste, Suriname, Zambia }\end{array}$ \\
\hline $\begin{array}{l}\text { Country/place of } \\
\text { birth of parents }\end{array}$ & $\begin{array}{l}\text { American Samoa, Aruba, Australia, Cyprus, Estonia, Faeroe Island, Guam, Italy, Israel, Liechtenstein, Lux- } \\
\text { embourg, Norfolk Island, Northern Mariana Islands, Palau, Sint Maarten (Dutch Part), Switzerland, United } \\
\text { States Virgin Islands }\end{array}$ \\
\hline $\begin{array}{l}\text { Country of previous } \\
\text { residence }\end{array}$ & $\begin{array}{l}\text { Afghanistan, Aruba, Bahamas, Bangladesh, Curacao, Estonia, Germany, Italy, Latvia, Luxembourg, Sint } \\
\text { Maarten (Dutch Part), Timor-Leste, Trinidad and Tobago }\end{array}$ \\
\hline $\begin{array}{l}\text { Receipt of } \\
\text { remittances }\end{array}$ & Armenia, Costa Rica, Ecuador, Malawi, Namibia, Romania, Tonga \\
\hline Reason for emigration & Djibouti, Lithuania, Mauritius, Norfolk Island, Romania \\
\hline Duration of visit & Croatia, Curacao, Kazakhstan, Sint Maarten (Dutch part), United Kingdom \\
\hline $\begin{array}{l}\text { Legal status of } \\
\text { residency }\end{array}$ & Canada, Cayman Islands, Cook Islands, Hong Kong SAR of China \\
\hline $\begin{array}{l}\text { Country of residence } \\
\text { at a specified date in } \\
\text { the past }\end{array}$ & Dominican Republic, Estonia, Saint Lucia \\
\hline Country of residence & Djibouti, Kazakhstan, Estonia \\
\hline $\begin{array}{l}\text { Reason for return } \\
\text { migration }\end{array}$ & Bangladesh, Lithuania, Montenegro \\
\hline Refugee status & Kazakhstan, Bosnia and Herzegovina \\
\hline Purpose of visit & Kazakhstan, Croatia \\
\hline $\begin{array}{l}\text { Duration having } \\
\text { been living abroad }\end{array}$ & Malta, Trinidad and Tobago \\
\hline Year or period of return & Burkina Faso, Jamaica \\
\hline $\begin{array}{l}\text { Immigration of mother/ } \\
\text { father }\end{array}$ & Germany \\
\hline $\begin{array}{l}\text { Intention to live in } \\
\text { country continuously for } \\
\text { at least } 12 \text { months }\end{array}$ & Mauritius \\
\hline $\begin{array}{l}\text { Place of birth of parents } \\
\text { and grandparents }\end{array}$ & Isle of Man \\
\hline $\begin{array}{l}\text { Number of foreigners } \\
\text { in the household }\end{array}$ & Qatar \\
\hline $\begin{array}{l}\text { Place of residence of } \\
\text { absent household } \\
\text { members }\end{array}$ & Bhutan \\
\hline $\begin{array}{l}\text { Place of usual } \\
\text { residence in the past } \\
6 \text { months }\end{array}$ & Macao SAR of China \\
\hline
\end{tabular}


Table 2, continued

\begin{tabular}{ll}
\hline Topic of question & Countries \\
\hline $\begin{array}{l}\text { Country of residence of } \\
\text { parents }\end{array}$ & Colombia \\
$\begin{array}{l}\text { Country of permanent } \\
\text { residence }\end{array}$ & Russian Federation \\
$\begin{array}{l}\text { Displacement/ } \\
\text { resettlement } \\
\text { due to war }\end{array}$ & Liberia \\
$\begin{array}{l}\text { Emigration of neighboring } \\
\text { household }\end{array}$ & Egypt \\
Oversea worker & Philippines \\
\hline
\end{tabular}

Source: United Nations Department of Economic and Social Affairs: Statistics Division (2016).

"place of birth" and publish tabulations crossing both variables with other relevant characteristics. However, in the 2010 census round only 66 percent of all countries collecting information on place of birth and citizenship did so for both. Almost half of all North American countries (46\%), 50 percent of South American countries and 55 percent of Asian countries asked both questions. In Africa and Oceania 70 percent and 77 percent of all countries included both questions respectively. Highest prevalence was found in Europe with $87 \%$ of all census questionnaires including the questions on "place of birth" and "citizenship."

Only one third of countries followed the recommendations provided by the UN Statistics Division and integrated all three core questions in their census questionnaire. This number is lowest in Asian and African countries, where only nine percent (3 out of 33) and 13 percent ( 4 out of 30) of census questionnaires included all three core questions respectively. In both, North and South America, all three questions are included in 10 out of 24 and 4 out of 10 census questionnaires respectively. Highest adherence to these international principles and recommendations are found in Oceania and Europe. Half of all censuses in Oceania (11 out of 22) asked the respondents about their country of birth, country of citizenship and year or time of arrival; in Europe 63 percent of all censuses followed these guidelines (19 out of 30).

Additional questions within the thematic area of international migration that were included in census questionnaires of the 2010 census round refer to: previous country of residence; duration of intended stay; and reason for arrival/return [28]. Fifty-three countries included a question on the emigration of household members, and thirty-four countries asked their respondents if they had ever lived abroad. A question relating to the reason for immigration appeared in twenty census questionnaires; eighteen countries in- cluded a question on the country where parents were born, and the census of the Isle of Man asked the birthplace of grandparents. A total of 19 countries collected data on the period of return of the native-born population [29]. Most of the countries that collected this information were European countries (10) followed by North America, however mostly Caribbean Island States (5). Fifteen countries asked about the country of previous residence, seven asked about receipt of remittances by the household, and five countries asked for the primary reason for emigration and the (intended) duration of stay/visit. Individual countries included unique questions, e.g. regarding the emigration of a neighboring household; or the country of permanent residence of self and parents. Figure 8 displays the frequency distribution of questions (number of censuses), and Table 2 provides information on the specific countries that included select questions in their census questionnaires.

While most migration related questions formed part of the individual or household questionnaires, the countries of Djibouti, Namibia, Bermuda and Romania designed a specific questionnaire to collect information on their emigrant population.

\section{Conclusion}

As migration, migrants and mobility are increasingly being considered in the context of global development and in national planning strategies, the demand for timely, accurate, nationally relevant and internationally comparable migration data and indicators is expected to rise.

Within the context of the call to disaggregate all relevant Sustainable Development Goal indicators by migration status (SDG indicator 17.18.1), the current review was undertaken to assess the number of popula- 
tion and housing censuses that collected core question on migration status in the 2010 census round, thereby enabling such disaggregation.

The finding that 87 percent of the 149 countries for which census questionnaire information are available included a question about country of birth, suggests that disaggregation of SDG data by foreign-born status should be possible for the majority of countries.

However finding that only 66 percent of all censuses included both questions on country of birth and citizenship limits our analytical purposes in the area of integration and discrimination. Further, the finding that only 50.3 percent asked for the year or period of arrival will limit opportunities to disaggregate by length of migration. All future population and housing censuses should be encouraged to include these core questions.

The variety of migration-related questions being asked within different national censuses offers a range of future options for standardization, and we encourage consideration of an expanded set of questions that may differentiate important vulnerabilities and shortfalls among migrants; empirical analysis is warranted to identify such potential questions.

Noting that the population census could only provide data at five or ten-year intervals, other data sources, such as registers, other administrative sources and sample surveys, should also be exploited in order to produce complete and accurate migration statistics, in particular for migration flow analysis.

However, complementary use of the variety of sources is hampered by the lack of data sharing between administrative data collection institutions and national statistical offices, and inconsistencies in the concepts and definitions among different sources exist.

As such, we need to continue promoting the idea that the presentation of migration data be accompanied by comprehensive metadata.

The focus of this paper was to identify the potential of population and housing censuses for measurement of international migration, understood as migrant stock. While the authors recognize migrant flows among the primary mechanism of population change, other than deaths, that directly influences the number of migrants, information on migrant flow cannot be captured by decennial censuses. Primary data sources for migrant flow statistics are population register and administrative data. Further, data on migrant flow are very limited. Based on the report "International Migration Flows to and from Selected Countries: The 2015 Revision" by the United Nations Population Division, we know that only 45 countries have relatively complete sets of data on international migration flows, an increase from 29 countries in 2008.

Finally, collection of census data does not consistently translate into the widespread availability of such data, even to government researchers, let alone to interested citizens of the countries concerned. It is important to advocate for the greater release of population and census data, and to exploit migration data to their fullest use. This appeal is consistent with the report of the Secretary-General on international migration statistics, presented to the United Nations Statistical Commission at its 45th session in 2016, which emphasized that more needs to be done to encourage the tabulation and dissemination of international migration data from population and housing censuses in order to enhance the exchange of statistical information between countries, the identification of factors contributing to human vulnerability, and to inform public policies that will "serve first those furthest behind" [30].

\section{References}

[1] United Nations, Department of Economic and Social Affairs, Population Division (2015). Trends in International Migrant Stock: The 2015 Revision (United Nations database, POP/DB/MIG/Stock/Rev.2015).

[2] United Nations General Assembly (2015). Transforming our world: the 2030 Agenda for Sustainable Development. Resolution adopted by the General Assembly on 25 September 2015. United Nations: A/RES/70/1. Page: 8.

[3] Juran, S. (2016). Crossing the Border. New York.

[4] Santo, PA., Summers, T., Summers, L.H. and Clemens, M. (2009). Migrants Count - Five Steps Toward Better Migration Data. Report of the Commission on International Migration Data for Development Research and Policy. 2009 Center for Global Development.

[5] Organisation for Economic Co-operation and Development (2016). International Migration Database. Last retrieved: 15 September 2016. https://stats.oecd.org/Index.aspx?DataSet Code $=$ MIG

[6] United Nations Population Fund (2016). Census. Last retrieved: 11 August 2016. http://www.unfpa.org/census.

[7] Bilsborrow, R.E., Hugo, G., Oberai, A.S. and Hania, Z. (1997). International Migration Statistics: Guidelines for improving data collection systems. Geneva: International Labour Organization. Page: 52

[8] Bilsborrow, R.E., Hugo, G., Oberai, A.S. and Zlotnik, H. (1997). International Migration Statistics: Guidelines for improving data collection systems. Geneva: International Labour Organization. Page: 53.

[9] Organisation for Economic Co-operation and Development (2016). International Migration Database. Last retrieved: 15 September 2016. https://stats.oecd.org/Index.aspx?DataSet Code $=$ MIG

[10] Santo, PA., Summers, T., Summers, L.H. and Clemens, M. (2009). Migrants Count - Five Steps Toward Better Migration 
Data. Report of the Commission on International Migration Data for Development Research and Policy. 2009 Center for Global Development.

[11] Helleringer, S. (2015). Monitoring Demographic Indicators for the Post 2015 Sustainable Development Goals (SDGs) A Review of Proposed Approaches and Opportunities. International Union for the Scientific Study of Population (IUSSP).

[12] Bilsborrow, R.E., Hugo, G., Oberai, A.S. and Zlotnik, H. (1997). International Migration Statistics: Guidelines for improving data collection systems. Geneva: International Labour Organization. Page: 53.

[13] United Nations (2014). Report of the Secretary-General on International migration and development. United Nations General assembly. A/69/207.

[14] Santo, P.A., Summers, T., Summers, L.H. and Clemens, M. (2009). Migrants Count - Five Steps Toward Better Migration Data. Report of the Commission on International Migration Data for Development Research and Policy. 2009 Center for Global Development

[15] United Nations Department of Economic and Social Affairs. Statistics Division (2016). UN Data Portal. Last Retrieved 15 September 2016. Available at: http://data.un.org/.

[16] United Nations Department of Economic and Social Affairs. Statistics Division (2016). Demographic Yearbook. Last Retrieved 15 September 2016. Available at: http://unstats.un.org/ unsd/demographic/products/dyb/dybcensusdata.htm.

[17] Juran, S. and Pistiner, A.L. (forthcoming). The 2010 Round of Population and Housing Censuses (2005-2014). Under Revision: Journal of the International Association for Official Statistics.

[18] United Nations Department of Economic and Social Affairs. Statistics Division (2012). Website of the 2010 World Population and Housing Census Program. Last Retrieved 15 September 2016. Available at: http://unstats.un.org/ unsd/demographic/sources/census/censusdates.htm.

[19] United Nations Department of Economic and Social Affairs. Statistics Division (2008). Principles and Recommendations for Population and Housing Censuses (P\&R), Censuses, Revision 2. United Nations. ST/ESA/STAT/SER.M/67/Rev.2.

[20] Santo, P.A., Summers, T., Summers, L.H., and Clemens, M. (2009). Migrants Count - Five Steps Toward Better Migration Data. Report of the Commission on International Migration Data for Development Research and Policy. 2009 Center for Global Development.
[21] Osaki-Tomita, K. (2012). Data Collection on International Migration. Background Paper prepared for the Tenth Coordination Meeting on International Migration. New York, 9 to 10 February 2012. United Nations Department of Economic and Social Affairs. Population Division.

[22] United Nations Department of Economic and Social Affairs. Statistics Division (2016). Principles and Recommendations of Population and Housing Censuses. Revision 3.

[23] United Nations Department of Economic and Social Affairs. Statistics Division (2016). 2020 World Population and Housing Census Programme. Last retrieved: 11 August 2016. http://unstats.un.org/unsd/demographic/sources/census/censu squest.htm.

[24] United Nations Department of Economic and Social Affairs. Statistics Division (2013). Implementation of United Nations recommendations for population census topics in the 2010 round. United Nations Secretariat. ESA/STAT/AC.277/4.

[25] United Nations Department of Economic and Social Affairs. Statistics Division (2013). Implementation of United Nations recommendations for population census topics in the 2010 round. United Nations. ESA/STAT/AC.277/4. Page: 14.

[26] Osaki-Tomita, K. (2012). Data Collection on International Migration. Background Paper prepared for the Tenth Coordination Meeting on International Migration. New York, 9 to 10 February 2012. United Nations Department of Economic and Social Affairs. Population Division.

[27] United Nations Department of Economic and Social Affairs. Statistics Division (2013). Implementation of United Nations recommendations for population census topics in the 2010 round. United Nations Secretariat. ESA/STAT/AC.277/4.

[28] United Nations Department of Economic and Social Affairs. Statistics Division (2013). Implementation of United Nations recommendations for population census topics in the 2010 round. United Nations Secretariat. ESA/STAT/AC.277/4.

[29] United Nations Department of Economic and Social Affairs. Statistics Division (2013). Implementation of United Nations recommendations for population census topics in the 2010 round. United Nations Secretariat. ESA/STAT/AC.277/4. Page: 16.

[30] United Nations (2014). Report of the Secretary-General on International migration and development. United Nations General assembly. A/69/207. 